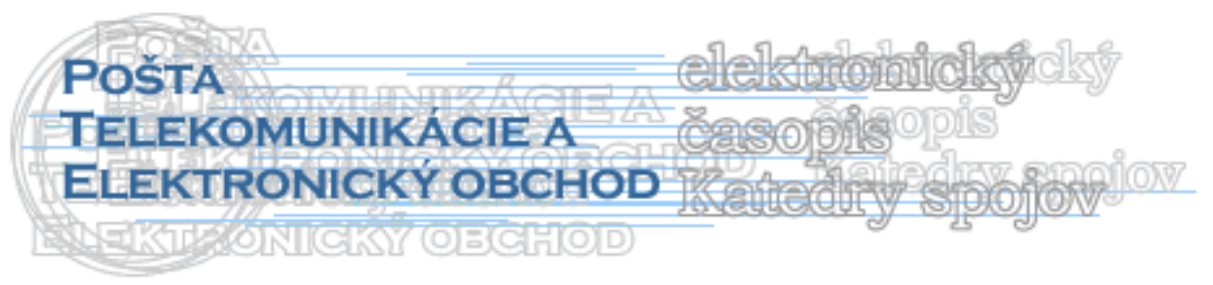

\title{
DAŇOVÁ KONTROLA
}

\section{Lucia Krátka*}

Úvod

Správa daní je rozsiahla a rôznorodá činnost', zahíňa evidenciu a registráciu daňových subjektov a ich vyhl'adávanie, overovanie podkladov potrebných na správne a úplné zistenie dane, daňové konanie, daňovú kontrolu, evidovanie daní a preddavkov, daňové exekučné konanie a iné činnosti správcov daní. [1]

Podla §1a pism. j) zákona o správe daní zamestnancom správcu dane je zamestnanec, ktorého zamestnávatel'om je:

1. DR SR,

2. colný úrad alebo Colné riaditel'stvo SR alebo

3. obec. [7]

Osobitný hmotnoprávny daňový zákon ukladá príslušnost' správcu dane ku konkrétnej dani. Správca dane doručí daňovému subjektu písomné oznámenie o výkone daňovej kontroly, ktoré obsahuje dátum začatia daňovej kontroly, miesto konania daňovej kontroly, druh kontrolovanej dane a kontrolované zdaňovacie obdobie. Daňovú kontrolu môže správca dane vykonat' aj bez oznámenia, ak o jej vykonanie požiadajú orgány činné v trestnom konaní alebo ak je podozrenie, že hrozí, že doklady budú zničené alebo pozmenené.

Daňový úrad ako správca dane, môže vykonat' daňovú kontrolu na jednotlivých daniach alebo súčasne na všetkých, na ktorých je daňový subjekt zaregistrovaný u tohto správcu dane. Daňový úrad vykonáva daňovú kontrolu v obvode svojej územnej pôsobnosti, ktorú ustanovuje zákon č. 150/2001 Z.z. o daňových orgánoch.

Zamestnanec správcu dane daňovou kontrolou zist'uje a preveruje základ dane alebo iné skutočnosti rozhodujúce pre správne určenie dane alebo vznik daňovej povinnosti, a to u daňového subjektu alebo na mieste, kde to účel kontroly vyžaduje.

\section{Daňová kontrola}

Daňová kontrola je jednou z rozhodujúcich činností správcu dane v rámci výkonu správy daní, na základe ktorej správca dane zist’uje alebo preveruje základ dane alebo iné skutočnosti rozhodujúce pre správne určenie dane, alebo vznik daňovej povinnosti. Daňová kontrola je jedným z procesných nástrojov, ktorým si správca dane má možnost' zistit', či daňový subjekt správne stanovil daňový základ, či priznaná daň daňovým subjektom v ním podanom daňovom priznaní bola správne vypočítaná v súlade s jednotlivými hmotnoprávnymi daňovými zákonmi, ako aj iné skutočnosti rozhodujúce pre vyrubenie dane. [3]

\footnotetext{
* Ing. Lucia Krátka, Žilinská univerzita v Žiline, Fakulta prevádzky a ekonomiky dopravy a spojov, Katedra spojov, Univerzitná 1, 01026 Žilina e-mail: kratka@fpedas.uniza.sk
} 
Daňová kontrola je základným aktom daňového konania a na daňové účely sa ňou rozumie podrobné preskúmanie účtovných prípadov a všetkých dokladov potrebných na určenie daňovej povinnosti z hl'adiska ich hodnovernosti, úplnosti a správnosti. [1]

Daňový subjekt, u ktorého sa vykonáva daňová kontrola, má vo vzt’ahu k zamestnancovi správcu dane tieto povinnosti:

- umožnit' poverenému zamestnancovi správcu dane vykonat' daňovú kontrolu,

- zabezpečit' vhodné miesto a podmienky na vykonanie daňovej kontroly,

- poskytovat' požadované informácie sám alebo ním určenou osobou,

- predkladat' účtovné a iné doklady, ktoré preukazujú hospodárske operácie a účtovné prípady $\mathrm{v}$ písomnej alebo technickej forme vrátane evidencie a záznamov, ktorých vedenie bolo správcom dane uložené, a podávat' k nim ústne alebo písomné vysvetlenia,

- predkladat' v priebehu daňovej kontroly všetky dôkazné prostriedky preukazujúce jeho tvrdenia,

- umožňovat' vstup do sídla kontrolovaného daňového subjektu a do jeho prevádzkových priestorov a umožňovat' rokovanie s jeho zamestnancom,

- zapožičat' doklady a iné veci mimo sídla alebo prevádzkových priestorov kontrolovaného daňového subjektu.

Daňový subjekt, u ktorého sa daňová kontrola vykonáva má vo vzt’ahu k zamestnancovi správcu dane právo:

- na predloženie služobného preukazu zamestnancom správcu dane a písomného poverenia zamestnanca správcu dane na výkon daňovej kontroly,

- byt' prítomný na rokovaní so svojimi zamestnancami,

- predkladat' v priebehu daňovej kontroly dôkazy preukazujúce jeho tvrdenia,

- nahliadnut' do zápisnice $\mathrm{z}$ miestneho zist'ovania vykonaného u iného daňového subjektu v súvislosti s daňovou kontrolou vykonávanou u kontrolovaného daňového subjektu,

- klást' svedkom a znalcom otázky pri ústnom pojednávaní,

- vyjadrit' sa ku skutočnostiam zisteným pri daňovej kontrole, k spôsobu ich zistenia, prípadne navrhnút', aby v protokole boli uvedené jeho vyjadrenia k nim,

- nahliadnut' do zapožičaných dokladov u správcu dane v jeho obvyklej úradnej dobe.

\section{Protokol musí obsahovat':}

a) názov a sídlo správcu dane,

b) číslo konania,

c) meno, priezvisko, adresu trvalého pobytu kontrolovaného daňového subjektu alebo

obchodné meno a sídlo kontrolovaného daňového subjektu, identifikačné číslo

organizácie a daňové identifikačné číslo kontrolovaného daňového subjektu (§ 31 ods.

11), ak mu bolo pridelené,

d) predmet daňovej kontroly a kontrolované zdaňovacie obdobie,

e) meno a priezvisko zamestnanca správcu dane, ktorý vykonáva daňovú kontrolu,

f) miesto vykonávania daňovej kontroly a dátum začatia daňovej kontroly,

g) súpis kontrolovaných dokladov,

h) preukázané kontrolné zistenia,

i) dátum vypracovania protokolu,

j) dátum prerokovania protokolu,

k) vlastnoručný podpis zamestnanca správcu dane, ktorý vykonáva daňovú kontrolu,

1) vlastnoručný podpis kontrolovaného daňového subjektu alebo ním povereného zástupcu. [7] 
Daňové konanie je konanie, v ktorom sa rozhoduje o právach a povinnostiach daňových subjektov. Predstavuje súhrn právnych úkonov daňových subjektov a správcu dane, vedúcich $\mathrm{k}$ určeniu daňových povinností a k vyberaniu daní. [2]

\section{Priebeh daňového konania}

Daňové konanie je súčast'ou správy daní, je to zákonom regulovaný postup správcu dane a účastníkov daňového konania, ktorého účelom je zabezpečit' správne vyrubenie a vybratie daní.

Daňové konanie prebieha v týchto etapách:

1. prípravné konanie,

2. vyrubovacie konanie,

3. vyberacie konanie,

4. daňové exekučné konanie,

5. konanie o opravných prostriedkoch. [7]

Prípravné konanie sa začína plnením registračnej a oznamovacej povinnosti daňových subjektov a končí vydaním osvedčenia o registrácii. Registračná a oznamovacia povinnost' je zákonom určená a na jej splnenie je stanovená 30 dňová lehota od právoplatnosti povolenia, oprávnenia na podnikanie alebo vykonávanie inej zárobkovej činnosti. Zmeny vykonané po registrácii je povinnost' nahlásit' do 15 dní po ich vzniku.

\section{Vyrubovacie konanie}

Každý komu vzniká v súlade so zákonom o správe daní alebo s osobitným daňovým zákonom daňová povinnost' alebo kto bol vyzvaný správcom dane, je povinný podat' daňové priznanie alebo hlásenie. Daňovým priznaním daňový subjekt deklaruje výšku daňovej povinnosti, ktorú je správca dane oprávnený preverit' daňovou kontrolou. Daň je vyrubená podaním daňového priznania alebo hlásenia, resp. podaním dodatočného daňového priznania alebo hlásenia. Po vykonaní daňovej kontroly sa daň vyrubuje výlučne rozhodnutím správcu dane, a to podl'a povahy zistených skutočností platobným výmerom alebo dodatočným platobným výmerom.

\section{Vyberacie konanie}

Daň vyrubená podaním daňového priznania alebo hlásenia je splatná v lehote na podanie daňového priznania alebo hlásenia. Daň vyrubená podaním dodatočného daňového priznania alebo hlásenia je splatná v lehote na ich podanie. Daň, ktorú je vyrubená rozhodnutím správcu dane formou platobného alebo dodatočného platobného výmeru je splatná do 15 dní odo dňa nadobudnutia právoplatnosti rozhodnutia.

Daň sa platí na číslo účtu miestne príslušnému správcovi dane bezhotovostným prevodom z účtu vedeného v banke alebo v hotovosti poštovou poukážkou.

Daňové exekučné konanie je konaním správcu dane, v ktorom sa vymáha nedoplatok a úhrada exekučných nákladov od daňového dlžníka. Exekučným titulom je právoplatné a vykonatel'né rozhodnutie správcu dane, ktorým bolo uložené peňažné plnenie a vykonatel'ný výkaz nedoplatkov. Výkaz daňových nedoplatkov zostavuje správca dane zúdajov v evidencii daní.

Konanie o opravných prostriedkoch zahrnuje konanie o riadnych a mimoriadnych opravných prostriedkoch. Právo na podanie opravného prostriedku je významným oprávnením daňového subjektu, ktorým sa môže domáhat' preskúmania rozhodnutia vydaného správcom dane, ako aj jemu predchádzajúceho konania, za účelom dosiahnutia nápravy. 
V rámci etáp daňového konania možno rozlíšit’ jednotlivé štádiá konania:

- začatie konania (Začína sa na návrh daňového subjektu alebo z úradnej moci. Návrh na začatie daňového konania označuje zákon ako podanie a samotné konanie začína jeho doručením orgánu príslušnému konat' vo veci alebo dňom, ked' daňový subjekt na výzvu tohto príslušného orgánu doručil doplnené podanie odvolanie, reklamácia, námietka),

- priebeh konania (Od začatia konania začne plynút' správcovi dane lehota na vydanie rozhodnutia. Počas tejto lehoty je správca dane povinný zistit' všetky skutočnosti rozhodujúce pre správny postup a rozhodnutie vo veci. V rámci svojej činnosti doručuje daňovému subjektu písomnosti, určuje mu lehoty na rozhodnutie, uskutočňuje miestne zist'ovania a pod.),

- prerušenie konania (Ak sa vyskytnú okolnosti, ktoré ovplyvňujú priebeh a znemožňujú v konaní pokračovat' zákon umožňuje alebo prikazuje prerušit' konanie a zastavit' konanie.),

- zastavenie konania (Správca dane je povinný koanie zastavit', ak nastane niektorá zo zákonom stanovených okolností, ktoré majú povahu prekážok trvalo znemožňujúcich pokračovanie v konaní),

- skončenie konania . [7]

Podl'a zákona o správe daní sa daňová kontrola vykonáva v rozsahu, ktorý je nevyhnutne potrebný na dosiahnutie účelu podl'a tohto zákona alebo osobitného predpisu (zákon o účtovníctve). Daňový úrad je oprávnený podl'a zákona o účtovníctve vykonávat' v účtovnej jednotke kontrolu dodržiavania ustanovení tohto zákona, kontrolu účtovníctva môže vykonávat' aj samostatne a nielen ako súčast' daňovej kontroly niektorej dane.

Okrem účtovných a iných dokladov, ktoré predkladá kontrolovaný daňový subjekt v písomnej alebo technickej forme, je povinný podat' na požiadanie písomné vysvetlenia k závažným zisteniam ovplyvňujúcim výšku dane.

O výsledku zistenia vyhotoví zamestnanec správcu dane protokol o daňovej kontrole, ktorý doručí kontrolovanému daňovému subjektu spolu s výzvou na jeho vyjadrenie a prerokovanie protokolu o daňovej kontrole; vo výzve určí dátum prerokovania protokolu o daňovej kontrole, pričom prerokovanie protokolu o daňovej kontrole sa môže uskutočnit' až po uplynutí lehoty na vyjadrenie kontrolovaného daňového subjektu k tomuto protokolu. Kontrolovaný daňový subjekt je oprávnený písomne sa vyjadrit' k protokolu o daňovej kontrole najneskôr do ôsmich pracovných dní odo dňa jeho doručenia.

Po prerokovaní protokolu o daňovej kontrole protokol podpisuje kontrolovaný daňový subjekt alebo jeho zástupca a zamestnanec správcu dane. Odmietnutie podpisu kontrolovaným daňovým subjektom alebo jeho zástupcom zamestnanec správcu dane v protokole zaznamená spolu s dôvodom odmietnutia, ak je mu známy. Jedno vyhotovenie protokolu odovzdá zamestnanec správcu dane kontrolovanému daňovému subjektu alebo jeho zástupcovi. Deň prerokovania protokolu je dňom jeho doručenia.

Daňovú kontrolu nemožno vykonat' po uplynutí piatich rokov od konca roka, v ktorom vznikla povinnost' podat' daňové priznanie alebo hlásenie, alebo v ktorom bol daňový subjekt povinný daň zaplatit' bez povinnosti podat' daňové priznanie alebo hlásenie, alebo v ktorom bol daňový subjekt povinný daň zaplatit' bez povinnosti podat' daňové priznanie alebo hlásenie, v ktorom bol daňový subjekt povinný daň zaplatit' bez povinnosti podat' daňové priznanie alebo hlásenie, alebo $\mathrm{v}$ ktorom daňovému subjektu vznikol nárok na vrátenie nadmerného odpočtu alebo nárok na vrátenie dane. Ak ide o daňový subjekt, ktorý si uplatňuje odpočítanie daňovej straty podl'a ZDP, nemožno vyrubit' daň ani rozdiel dane po 
uplynutí siedmich rokov od konca roka, v ktorom vznikla povinnost' podat' daňové priznanie, a v ktorom bola táto daňová strata vykázaná.

Daňová kontrola je ukončená dňom prerokovania protokolu o daňovej kontrole s kontrolovaným daňovým subjektom alebo jeho zástupcom. Dňom nasledujúcim po dni prerokovania protokolu o daňovej kontrole sa začína vyrubovacie konanie. Doručenie protokolu o daňovej kontrole sa považuje za úkon smerujúci k vyrubeniu dane alebo rozdielu dane.

Dôkazné bremeno je na strane daňového subjektu. Správca dane pri výkone daňovej kontroly vychádza z prezumpcie neviny, t.j. kým sa nepreukáže opak. Ak sa zistia skutočnosti, následkom ktorých dôjde k úprave daňovej povinnosti oproti daňovému priznaniu, má správca dane povinnost' v súlade s právnymi predpismi dokázat' daňovému subjektu, že postupoval nesprávne, poučit' ho o správnom postupe a o následkoch, ktoré bude znášat' za nesprávny výpočet dane $\mathrm{v}$ daňovom priznaní, a o zaplatení dane v nesprávnej výške. Účelom daňovej kontroly je teda aj zistenie, či si daňové subjekty splnili v súlade s príslušnými hmotnoprávnymi predpismi všetky svoje povinnosti voči štátnemu rozpočtu. Ked’že ide o fiškálne záujmy štátu, preto zákon o správe daní zakotvil inštitút daňovej kontroly a inštitút opakovanej daňovej kontroly. [5]

\section{Opakovaná daňová kontrola}

Podl'a zákona o správe daní a poplatkov opakovanou daňovou kontrolou sa rozumie daňová kontrola u daňového subjektu tej istej dane za zdaňovacie obdobie, za ktoré už bola vykonaná:

a. ak daňový subjekt žiada o vrátenie dane dodatočným daňovým priznaním alebo dodatočným hlásením,

b. ak daňový subjekt žiadal o vrátenie dane podl'a osobitného hmotnoprávneho daňového zákona,

c. na podnet MF SR, DR SR alebo CR SR.

Opakovanou daňovou kontrolou nie je:

- preverenie výsledkov daňovej kontroly v rámci konania o riadnych opravných prostriedkoch alebo mimoriadnych opravných prostriedkoch,

- daňová kontrola na základe žiadosti orgánov činných v trestnom konaní.

Opakovanú daňovú kontrolu možno vykonat' vtedy, ak správca dane skončí daňovú kontrolu, t.j. prerokuje protokol o daňovej kontrole s daňovým subjektom alebo jeho zástupcom, alebo ak sa daňový subjekt alebo jeho zástupca nezúčastní na prerokovaní protokolu v deň určený vo výzve, považuje sa za deň prerokovania a doručenia protokolu deň, ktorý je určený vo výzve na prerokovanie tohto protokolu. Pretože na ukončenie daňovej kontroly nadväzuje vyrubovacie konanie, opakovanú daňovú kontrolu možno začat' až po právoplatnom vyrubení dane alebo rozdielu dane z daňovej kontroly. [4]

\section{Záver}

Podkladom na výpočet dane z príjmov právnických osôb je podvojné účtovníctvo, kde sa základ dane vypočíta zo zisteného účtovného výsledku hospodárenia, ktorý sa vyčísl'uje z podkladov a údajov riadne vedeného účtovníctva daňovníka. Ked’že daňový základ, ktorý je vymedzený zákonom o dani z príjmov, získame vhodnou transformáciou účtovného výsledku hospodárenia pred zdanením, je potrebné aby daňový subjekt zvolil vhodnú analytickú evidenciu najmä pokial' ide o daňovo uznatel'né náklady, ktoré sú vymedzené zákonom a do značnej miery ovplyvňujú (zvyšujú alebo znižujú) daňový základ. Teda predmetom daňovej kontroly je aj vhodne zvolená analytická evidencia, ktorej vedenie účtovnej jednotke vyplýva zo zákona o účtovníctve. 


\section{Literatúra}

[1] KRÁTKA, L.: Výskum štruktúry a obsahu analytickej evidencie nákladov pre účely výpočtu a kontroly daní v siet'ových podnikoch, In: Písomná práca $\mathrm{k}$ štátnej dizertačnej skúške,2009. Žilinská univerzita v Žiline, Fakulta prevádzky a ekonomiky dopravy a spojov, Katedra spojov.

[2] BIELIKOVÁ, A. A ŠTOFKOVÁ, K.: Dane v teórii a praxi, Žilina, Žilinská univerzita v Žiline, 2010, ISBN 978-80-554-0169-0

[3] Mrvová, M.: Daňová kontrola a opakovaná daňová kontrola - 1. čast', Dane a účtovníctvo v praxi 7-8/2010, Bratislava, Iura Edition, 2010

[4] Mrvová, M.: Daňová kontrola a opakovaná daňová kontrola - 2. čast', Dane a účtovníctvo v praxi 9/2010, Bratislava, Iura Edition, 2010

[5] CHORVÁTOVÁ, J. - BORÁKOVÁ, M. - GALOVÁ, J. - HAŠČÍKOVÁ, Š. JAROŠOVÁ, B.: Dane 2006, Systém ekonomických a právnych informácií s.r.o., Žilina, 2006, ISBN 80-88961-30-0

[6] Zákon č. 595/2003 Z. z. o dani z príjmov

[7] Zákon č. 511/1992 Z. z. o správe daní a poplatkov k 1.1.2010

[8] www.drsr.sk

[9] www.finance.gov.sk 